\title{
PENGARUH CAR, NPL, BOPO, NIM, LDR TERHADAP ROA PADA PT BANK TABUNGAN NEGARA,TBK PERIODE TAHUN 2008-2020
}

\author{
Palupi Permata Rahmi, Listri Herlina \\ Sekolah Tinggi Ilmu Ekonomi Indonesia Membangun (STIE INABA) \\ palupi.permata@inaba.ac.id
}

\begin{abstract}
This study aims to analyze the effect of Capital Adequacy Ratio (CAR), Non Performing Loan (NPL), Operational Costs on Operating Income (BOPO), Net Interest Margin (NIM) and and Loan to Deposit Ratio (LDR) on Return on Assets (ROA). ) at PT Bank Tabungan Negara, Tbk for the period 2008-2020. The sample used in this study is PT Bank Tabungan Negara, Tbk for the period 2008-2020. This research uses descriptive and quantitative approaches. The results showed that partially CAR, BOPO and LDR had no significant effect on ROA at PT Bank Tabungan Negara, Tbk for the Period of 20082020. Meanwhile, NPL and NIM partially have a significant effect on ROA. Simultaneously, CAR, NPL, OEOI, NIM and LDR have a significant effect on ROA at PT Bank Tabungan Negara, Tbk for the Period of 2008-2020.
\end{abstract}

Keywords: $C A R, N P L, B O P O, N I M, L D R$, and ROA

\begin{abstract}
Abstrak
Penelitian ini bertujuan untuk menganalisis pengaruh Capital Adequacy Ratio(CAR), Non Performing Loan(NPL), Biaya Operasional terhadap Pendapatan Operasional (BOPO), Net Interest Margin (NIM) dan Loan to Deposit Ratio (LDR) terhadap Return on Asset (ROA) pada PT Bank Tabungan Negara,Tbk Periode Tahun 2008-2020. Sampel yang digunakan dalam penelitian ini adalah PT Bank Tabungan Negara,Tbk Periode Tahun 2008-2020. Penelitian ini menggunakan pendekatan metode deskriptif dan kuantitatif. Hasil penelitian menunjukkan bahwa secara parsial CAR, BOPO dan LDR tidak berpengaruh signifikan terhadap ROA pada PT Bank Tabungan Negara,Tbk Periode Tahun 2008-2020. Sedangkan NPL dan NIM secara parsial berpengaruh signifikan terhadap ROA. Secara simultan, CAR, NPL, BOPO, NIM dan LDR berpengaruh signifikan terhadap ROA pada PT Bank Tabungan Negara,Tbk Periode Tahun 20082020.
\end{abstract}

Kata kunci : CAR, NPL, BOPO, NIM, LDR, dan ROA

\section{Pendahuluan}

Bank umum memiliki peran penting dalam perekonomian suatu negara. Di tingkat makroekonomi, bank merupakan lembaga utama yang mentransmisikan kebijakan moneter, dan di tingkat mikroekonomi, bank merupakan sumber utama pembiayaan bagi individu dan bisnis (Koch \& Mac Donald, 2000). Menurut Undang-undang Nomor 7 tahun 1992 tentang Perbankan sebagaimana telah diubah dengan Undangundang nomor 10 tahun 1998 pengertian bank adalah badan usaha yang menghimpun dana dari masyarakat dalam bentuk simpanan dan menyalurkannya kepada masyarakat dalam bentuk kredit dan atau bentuk-bentuk lainnya dalam rangka meningkatkan taraf hidup rakyat banyak.
Dengan memiliki peran yang sangat penting dan vital dalam perekonomian, bank dituntut memiliki Kinerja yang baik karena kinerja perbankan yang buruk dapat menyebabkan kegagalan yang akan berdampak luas bagi pertumbuhan ekonomi suatu negara. Hal ini dikarenakan Sektor perbankan rentan dengan berbagai risiko, terutama risiko sistemik, yakni kegagalan bank yang berdampak terhadap ekonomi dalam jangka panjang.

Dampak yang muncul akibat kegagalan usaha bank menimbulkan perlunya dilakukan serangkaian analisis yang sedemikian rupa sehingga resiko kegagalan bank dapat dideteksi sedini mungkin, salah satu cara untuk mendeteksi risiko bank adalah dengan melihat kinerja perbankan. Bank Indonesia melakukan 
otoritas moneter menetapkan ketentuan standarisasi kemampuan menghasilkan pendapatan.

Peningkatan pendapatan atau keuntungan dari total aktiva yang dimiliki oleh bank dapat menggambarkan kondisi bank dan kemampuan pengelolaannya. Bank yang sehat adalah bank yang diukur secara rentabilitas yang terus meningkat.

Hal ini juga berkaitan dengan efisiensi dan kemampuan bank dalam melakukan kegiatan operasi, dengan adanya efisiensi biaya maka keuntungan yang diperoleh bank akan semakin besar. Sementara kinerja yang diperlihatkan perbankan dengan melihat indikator keuangan sangat menentukan kinerja bank tersebut.

Kinerja keuangan perbankan dapat dilihat dari beberapa indikator keuangan seperti CAR (Capital Adequacy Ratio) yang merupakan sebagai kecukupan pemenuhan KPMM (Kewajiban Penyediaan Modal Minimum) sesuai ketentuan yang berlaku. BOPO sebagai suatu indikator rentabilitas perbankan. LDR (Loan Deposit Ratio) untuk menunjukkan sebagai indikator likuiditas perbankan. Termasuk juga ROA (Return On Assets) serta NIM (Net Interest Margin). Menurut Vania Anindita and Achmad Herlanto Anggono (2016) salah satu yang paling mempengaruhi ROA perbankan adalah kredit macet (NPL), oleh karena itu bank seharusnya menjaga kualitas kreditnya daripada mendorong peningkatan penyaluran kredit. Hasil yang diperoleh akan menggambarkan kondisi bank umum dan kemampuan pengelolaannya.

Dengan melihat indikator tingkat kesalahan suatu bank kita dapat mengetahui pengaruh terhadap kinerja perbankan itu sendiri, sehingga memberikan probalilitas secara keseluruhan baik bagi bank tersebut serta dunia perbankan Indonesia. Pemerintah pada dasarnya sudah berupaya untuk memperbaiki kinerja perbankan nasional agar tidak membahayakan kelangsungan usahanya.

Berdasarkan uraian latar belakang di atas, maka penulis merasa tertarik untuk melakukan penelitian dengan judul "Pengaruh CAR, NPL, BOPO, NIM, dan LDR terhadap ROA pada PT Bank Tabungan Negara,Tbk Periode Tahun 20082020".

\section{Metode Penelitian}

Sugiyono (2018) menerangkan bahwa, "Metode penelitian diartikan sebagai cara ilmiah untuk mendapatkan data dengan tujuan dan kegunaan tertentu." Metode penelitian merupakan cara utama yang digunakan peneliti untuk mencapai tujuan dan menentukan jawaban atas masalah yang diajukan. Metode penelitian yang digunakan dalam penelitian ini adalah menggunakan metode kuantitatif dengan pendekatan deskriptif dan verifikatif.

\section{Operasionalisasi Variabel Penelitian}

Dalam penelitian ini terdapat 2 jenis variabel yang diteliti, yaitu variabel bebas (Independent Variabel) dan variabel terikat (Dependent Variabe). Definisi operasional untuk masing - masing variabel adalah sebagai berikut

1. Variabel Bebas (Independent Variabe) merupakan variabel yang mempengaruhi perubahan atau timbulnya variabel terikat (Dependent Variabe). Variabel bebas yang diteliti pada penelitian ini adalah CAR, NPL, BOPO, NIM, LDR.

2. Variabel Terikat (Dependent Variabe) merupakan variabel yang dipengaruhi atau yang menjadi akibat adanya variabel bebas. Variabel terikat yang diteliti pada penelitian ini adalah Return On Asset (ROA) (Y).

a. Return on Assets (ROA). Return On Asset (ROA) merupakan salah satu rasio profitabilitas yang dapat mengukur kemampuan perusahaan dalam menghasilkan laba dari aktiva yang digunakan (Taswan,2010). ROA dirumuskan sebagai berikut (SE BI No 6/73/INTERN/DPNP tgl 24 Desember 2004):

$$
\mathrm{ROA}=\frac{\text { Laba bersih sebelum pajak }}{\text { Total Aset }} \times 100 \%
$$

b. Capital Adequacy Ratio (CAR) yaitu Menurut Bank Indonesia (Nomor 9/13/PBI/2007) "CAR adalah penyediaan modal minimum bagi bank didasarkan pada risiko aktiva dalam arti luas, baik aktiva yang tercantum dalam neraca maupun aktiva yang bersifat administratif sebagaimana tercermin pada kewajiban yang masih bersifat kontijen dan/atau komitmen yang disediakan oleh bank bagi pihak ketiga maupun risiko pasar. CAR dirumuskan sebagai berikut (SE BI No 6/73/INTERN/DPNP tgl 24 Desember 2004): 


$$
C A R=\frac{\text { Modal }}{\text { ATMR }} \times 100 \%
$$

c. Non-Performing Loan (NPL), menunjukkan kemampuan manajemen bank dalam mengelola kredit bermasalah yang diberikan oleh bank. Apabila suatu bank kondisi NPL tinggi maka akan memperbesar biaya lainnya, sehingga berpotensi terhadap kerugian bank (Mawardi, 2005). NPL dirumuskan sebagai berikut (SE BI No 6/73/INTERN/DPNP tgl 24 Desember 2004):

$$
N P L=\frac{\text { Kredit Bermasalah }}{\text { Total Kredit }} \times 100 \%
$$

d. Biaya Operasional terhadap Pendapatan Operasional (BOPO). BOPO merupakan hasil pembagian antara total biaya operasional dengan total pendapatan operasional. dirumuskan sebagai berikut (SE BI No 6/73/INTERN/DPNP tgl 24 Desember 2004):

$$
\text { BOPO }=\frac{\text { Total Biaya Operasional }}{\text { Total Pendapatan Operasional }} \times 100 \%
$$

e. Rasio Net Interest Margin (NIM) Net Income Margin (NIM) merupakan rasio yang menunjukkan kemampuan manajemen bank dalam mengelola aktiva produktifnya untuk menghasilkan pendapatan bunga bersih. Pendapatan bunga bersih diperoleh dari pemberian kredit atau pinjaman, sementara bank memiliki kewajiban beban bunga kepada deposan (Almilia dan Herdiningtyas, 2005). NIM dirumuskan sebagai berikut (SE BI No 6/73/INTERN/DPNP tgl 24 Desember 2004):

$$
N I M=\frac{\text { Pendapatan Bunga Bersih }}{\text { Rata }- \text { Rata Aktiva Produktif }} \times 100 \%
$$

f. Rasio Loan to Deposit Ratio (LDR) merupakan rasio yang digunakan untuk mengukur kemampuan bank dalam membayar hutang dan membayar kembali kepada deposannya serta dapat memenuhi permintaan kredit yang diajukan (Pinasti dan Mustikawati, 2018). Sedangkan Menurut Kasmir (2014) "LDR (Loan to Deposit Ratio) adalah rasio yang digunakan untuk mengukur komposisi jumlah kredit yang diberikan dibandingkan dengan jumlah dana masyarakat dan modal sendiri yang digunakan." LDR dirumuskan sebagai berikut (SE BI No 6/73/INTERN/DPNP tanggal 24 Desember 2004):

$$
\mathrm{LDR}=\frac{\text { Total Kredit }}{\text { Total Dana Pihak Ketiga }} \times 100 \%
$$

\section{Jenis Sumber Data}

Jenis data yang digunakan dalam penelitian ini adalah data sekunder. Menururt Sugiyono (2018), sumber sekunder yaitu sumber yang tidak langsung memberikan data kepada pengumpul data misalnya lewat orang lain atau dokumen. Jenis data yang digunakan dalam penelitian ini yaitu data sekunder dan jenis data kuantitatif yang berupa laporan keuangan tahunan pada PT Bank Tabungan Negara,Tbk Periode 2008-2020.

\section{Teknik Pengumpulan Data}

Teknik pengumpulan data menggunakan teknik dokumentasi yaitu mengacu kepada bagaimana data yang diperlukan dapat diperoleh. Pengumpulan data yang digunakan oleh penulis adalah teknik studi pustaka dan pencarian data melalui internet. Studi pustaka adalah pengumpulan data melalui buku-buku, artikel, jurnal dan lainnya yang berhubungan dengan penelitian yang dilakukan penulis.

\section{Teknik Penarikan Sampel}

Teknik Penarikan Sampel menggunakan teknik pengambilan sampel yaitu purposive sampling yaitu sampel yang diambil berdasarkan kriteria-kriteria tertentu. Kriteria yang digunakan Peneliti untuk memilih sampel adalah sebagai berikut :

a. Perusahaan yang menyajikan data-data laporan keuangan yang lengkap terutama mengenai variabel-variabel dalam penelitian seperti CAR, NPL, BOPO, NIM, LDR dan ROA pada periode tahun 2008-2020.

b. Nilai Return On Assets (ROA) pada PT Bank Tabungan Negara,Tbk Periode Tahun 20082020.yang mengalami fluktuasi dengan kecenderungan turun.

c. Pemilihan sampel dalam penelitian ini adalah data laporan keuangan (Annual report) pada PT Bank Tabungan Negara,Tbk Sedangkan sampel yang peneliti ambil secara purposive sampling dengan data selama tiga belas tahun tahun terakhir pada 2008-2020 yang diperoleh dari annual report pada PT Bank Tabungan Negara,Tbk.

\section{Teknik Analisis Data dan Pengujian Hipotesis \\ Analisis Deskriptif \\ Menurut Sugiyono (2018), metode penelitian deskriptif ini dilakukan untuk}


mengetahui keberadaan variabel mandiri, baik hanya pada satu variabel atau lebih (variabel yang berdiri sendiri atau variabel bebas) tanpa membuat perbandingan variabel itu sendiri dan mencari hubungan dengan variabel lain.

\section{Analisis Verifikatif}

Analisis ini digunakan untuk menentukan seberapa kuatnya pengaruh variabel bebas $(X)$ yaitu $\operatorname{CAR}\left(X_{1}\right)$, NPL $\left(X_{2}\right)$, BOPO $\left(X_{3}\right)$, NIM $\left(X_{4}\right)$, LDR $\left(X_{5}\right)$, terhadap variabel terikat $(Y)$ yaitu Return On Assets (ROA) dengan menggunakan analisis regresi linear berganda. Adapun model penelitiannya adalah sebagai berikut :

$\mathrm{Y}=\mathrm{a}+\mathrm{b}_{1} \mathrm{X}_{1}+\mathrm{b}_{2} \mathrm{X}_{2}+\mathrm{b}_{3} \mathrm{X}_{3}+\mathrm{b}_{4} \mathrm{X}_{4}+\mathrm{b}_{5} \mathrm{X}_{5}+\mathrm{y}+\mathrm{e}$

Keterangan:

Y : Return Of Asset (ROA)

a : Konstanta

$\mathrm{X} 1$ : CAR

$X 2:$ NPL

$\mathrm{X} 3: \mathrm{BOPO}$

X4 : NIM

X5 : LDR

b1-b5 : Koefisien regresi, merupakan besarnya perubahan variabel terikat akibat perubahan tiap-tiap unit variabel bebas.

e : Kesalahan Residual (error)

\section{Pembahasan}

Analisis Deskriptif Variabel Penelitian 1. Analisis Deskriptif Variabel ROA

Berdasarkan hasil analisis deskriptif, gambaran setiap variabel dapat disajikan dalam bentuk tabel sebagai berikut:

\section{a. Variabel Return On Assets (ROA)}

Berikut adalah data Return On Assets (ROA) pada PT Bank Tabungan Negara,Tbk Periode Tahun 2008-2020.

Tabel 1.

Nilai ROA PT Bank Tabungan Negara,Tbk

\begin{tabular}{ccc}
\hline No & Tahun & ROA (\%) \\
\hline 1. & 2008 & 1,8 \\
2. & 2009 & 1,47 \\
3. & 2010 & 2,05 \\
4. & 2011 & 2,03 \\
5. & 2012 & 1,94 \\
6. & 2013 & 1,79 \\
7. & 2014 & 1,14 \\
8. & 2015 & 1,61 \\
9. & 2016 & 1,76 \\
\hline
\end{tabular}

\begin{tabular}{ccc}
\hline No & Tahun & ROA (\%) \\
\hline 10. & 2017 & 1,71 \\
11. & 2018 & 1,34 \\
12. & 2019 & 0,13 \\
13. & 2020 & 0,69 \\
Nilai maksimum & & 2,05 \\
Nilai Minimum & & 0,13 \\
Nilai Rata-rata (mean) & & 1,4969 \\
Standar Deviasi & & 0,56005 \\
\hline
\end{tabular}

Sumber : Laporan Keuangan PT Bank Tabungan Negara,Tbk (2020), diolah.

Pada Tabel 1, menunjukan hasil pengamatan ROA pada PT Bank Tabungan Negara,Tbk periode 2008-2020 bahwa ROA mengalami kecenderungan penurunan tiap tahunnya. Pada tabel 1 tersebut dapat diliketahui bahwa ROA tertinggi berada di tahun 2010 yaitu 2,05\%, sedangkan ROA terendah berada di tahun 2019 yaitu sebesar 0,13. Pada Tabel 1 juga dapat diketahui nilai mean dan standar deviasi untuk ROA yaitu sebesar 1,4969 dan 0,56005 .

\section{b. Variabel Capital Adequacy Ratio (CAR)}

Berikut ini adalah Capital Adequacy Ratio (CAR) pada PT Bank Tabungan Negara,Tbk Periode Tahun 2008-2020.

\section{Tabel 2}

Nilai CAR PT Bank Tabungan Negara,Tbk

\begin{tabular}{ccc}
\hline No & Tahun & CAR $(\%)$ \\
\hline 1. & 2008 & 16,44 \\
2. & 2009 & 21,99 \\
3. & 2010 & 16,74 \\
4. & 2011 & 15,03 \\
5. & 2012 & 17,69 \\
6. & 2013 & 15,62 \\
7. & 2014 & 14,64 \\
8. & 2015 & 16,97 \\
9. & 2016 & 20,34 \\
10. & 2017 & 18,87 \\
11. & 2018 & 18,21 \\
12. & 2019 & 17,32 \\
13. & 2020 & 19,34 \\
Nilai maksimum & & 20,34 \\
Nilai Minimum & & 14,64 \\
Nilai Rata-rata (mean) & & 17,6308 \\
Standar Deviasi & & 2,11415 \\
\hline Sumber : Laporan Keuangan
\end{tabular}

Sumber : Laporan Keuangan a. PT Bank Tabungan Negara,Tbk (2020), diolah.

Berdasarkan tabel 2, maka dapat diketahui nilai CAR tertinggi berada di tahun 
2016 yaitu sebesar 20,34\%, sedangkan CAR terendah ada di tahun 2014 yaitu sebesar $14,64 \%$. Nilai rata-rata (mean) untuk CAR yaitu 17,6308, dengan standar deviasi sebesar 2,11415 .

\section{c. Variabel Non Performing Loan (NPL)}

Berikut ini adalah Non Performing Loan (NPL) pada PT Bank Tabungan Negara,Tbk Periode Tahun 2008-2020.

\section{Tabel 3}

Nilai NPL PT Bank Tabungan Negara,Tbk

\begin{tabular}{ccc} 
No & Tahun & NPL (\%) \\
\hline 1. & 2008 & 3,20 \\
2. & 2009 & 3,36 \\
3. & 2010 & 3,26 \\
4. & 2011 & 2,75 \\
5. & 2012 & 4,09 \\
6. & 2013 & 4,05 \\
7. & 2014 & 4,01 \\
8. & 2015 & 3,42 \\
9. & 2016 & 2,84 \\
10. & 2017 & 2,66 \\
11. & 2018 & 2,82 \\
12. & 2019 & 4,78 \\
13. & 2020 & 4,37 \\
Nilai maksimum & 4,78 \\
Nilai & Minimum & 2,66 \\
Nilai & Rata-rata & 3,5085 \\
(mean) & & \\
Standar Deviasi & 0,68586 \\
\hline
\end{tabular}

Sumber : Laporan Keuangan PT Bank Tabungan Negara,Tbk (2020),diolah.

Berdasarkan tabel 3, maka dapat diketahui nilai NPL tertinggi berada di tahun 2019 yaitu sebesar $4,78 \%$, sedangkan NPL terendah ada di tahun 2017 yaitu sebesar 2,66\%. Nilai rata-rata (mean) untuk NPL yaitu 3,5085, dengan standar deviasi sebesar 0,68586.

\section{d. Variabel Biaya Operasional Pendapatan Operasional (BOPO)}

Berikut ini adalah Non Performing Loan (NPL) pada PT Bank Tabungan Negara,Tbk Periode Tahun 2008-2020.

Tabel 4

Nilai BOPO PT Bank Tabungan

Negara,Tbk

\begin{tabular}{ccc}
\hline No & Tahun & BOPO (\%) \\
\hline 1. & 2008 & 86,18 \\
\hline
\end{tabular}

\begin{tabular}{ccc}
\hline No & Tahun & BOPO (\%) \\
\hline 2. & 2009 & 87,87 \\
3. & 2010 & 83,28 \\
4. & 2011 & 81,75 \\
5. & 2012 & 80,74 \\
6. & 2013 & 82,19 \\
7. & 2014 & 88,97 \\
8. & 2015 & 84,43 \\
9. & 2016 & 82,48 \\
10. & 2017 & 82,06 \\
11. & 2018 & 85,58 \\
12. & 2019 & 98,12 \\
13. & 2020 & 91,61 \\
Nilai maksimum & 98,12 \\
Nilai Minimum & 80,74 \\
\multicolumn{2}{l}{ Nilai Rata-rata (mean) } & 85,7892 \\
Standar Deviasi & 4,90186 \\
\hline
\end{tabular}

Sumber : Laporan Keuangan PT Bank Tabungan Negara,Tbk (2020), diolah.

Berdasarkan tabel 4, maka dapat diketahui nilai BOPO tertinggi berada di tahun 2019 yaitu sebesar 21,99\%, sedangkan BOPO terendah ada di tahun 2012 yaitu sebesar $80,74 \%$. Nilai rata-rata (mean) untuk CAR 85,7892, dengan standar deviasi sebesar 4,90186 .

\section{e. Variabel Net Interest Margin (NIM)}

Berikut ini adalah Net Interest Margin (NIM) pada PT Bank Tabungan Negara,Tbk Periode Tahun 2008-2020.

Tabel 5

Nilai NIM PT Bank Tabungan Negara,Tbk

\begin{tabular}{llr}
\hline No & Tahun & NIM (\%) \\
\hline 1. & 2008 & 5,08 \\
2. & 2009 & 4,65 \\
3. & 2010 & 5,93 \\
4. & 2011 & 5,75 \\
5. & 2012 & 5,83 \\
6. & 2013 & 5,44 \\
7. & 2014 & 4,47 \\
8. & 2015 & 4,87 \\
9. & 2016 & 4,98 \\
10. & 2017 & 4,76 \\
11. & 2018 & 4,32 \\
12. & 2019 & 3,32 \\
13. & 2020 & 3,06 \\
Nilai maksimum & \multicolumn{2}{c}{5,93} \\
Nilai Minimum & 3,06 \\
Nilai Rata-rata (mean) & 4,8046 \\
Standar Deviasi & \multicolumn{2}{c}{0,88255} \\
\hline
\end{tabular}


Sumber : Laporan Keuangan PT Bank Tabungan Negara,Tbk (2020),diolah.

Berdasarkan tabel 5, maka dapat diketahui nilai NIM tertinggi berada di tahun 2010 yaitu sebesar 5,93\%, sedangkan NIM terendah ada di tahun 2020 yaitu sebesar $3,06 \%$. Nilai rata-rata (mean) untuk NIM yaitu 4,8046, dengan standar deviasi sebesar 0,88255.

\section{f. Variabel Loan To Deposit Ratio (LDR)}

Berikut ini adalah Rasio Loan To Deposit Ratio (LDR) pada PT Bank Tabungan Negara,Tbk Periode Tahun 2008-2020.

\section{Tabel 6}

Nilai LDR PT Bank Tabungan Negara, Tbk

\begin{tabular}{ccc}
\hline No & Tahun & LDR $(\%)$ \\
\hline 1. & 2008 & 101,83 \\
2. & 2009 & 101,29 \\
3. & 2010 & 108,42 \\
4. & 2011 & 102,57 \\
5. & 2012 & 100,90 \\
6. & 2013 & 104,42 \\
7. & 2014 & 108,85 \\
8. & 2015 & 108,78 \\
9. & 2016 & 102,66 \\
10. & 2017 & 103,13 \\
11. & 2018 & 103,25 \\
12. & 2019 & 113,50 \\
13. & 2020 & 93,19 \\
Nilai maksimum & 108,85 \\
Nilai Minimum & 93,19 \\
Nilai Rata-rata (mean) & 104,0608 \\
Standar Deviasi & 4,99971 \\
\hline
\end{tabular}

Sumber : Laporan Keuangan PT Bank Tabungan Negara,Tbk (2020),diolah.

Berdasarkan tabel 6, maka dapat diketahui nilai LDR tertinggi berada di tahun 2014 yaitu sebesar 108,85\%, sedangkan LDR terendah ada di tahun 2020 yaitu sebesar $93,19 \%$. Nilai rata-rata (mean) untuk LDR yaitu 104,0608, dengan standar deviasi sebesar 4,99971 .

\section{Analisis Verifikatif}

Analisis ini digunakan untuk menentukan seberapa kuatnya pengaruh variabel bebas $(X)$ yaitu Capital Adequacy Ratio (CAR) ( $\mathrm{X}_{1}$, Non Performing Loan (NPL) $\left(\mathrm{X}_{2}\right)$, Biaya Operasional Pendapatan Operasional (BOPO) $\left(\mathrm{X}_{3}\right)$, Net Interest Margin (NIM) $\left(\mathrm{X}_{4}\right)$, dan Loan to Deposit
Ratio (LDR) $\left(\mathrm{X}_{5}\right)$ terhadap variabel terikat $(\mathrm{Y})$ yaitu Return On Assets (ROA).

\section{Analisis Regresi Linear Berganda}

Hasil analisis uji regresi linear berganda pada Tabel 7 dibawah ini :

\section{Tabel 7}

\section{Hasil Uji Regresi Linear Berganda} Coefficients ${ }^{\mathrm{a}}$

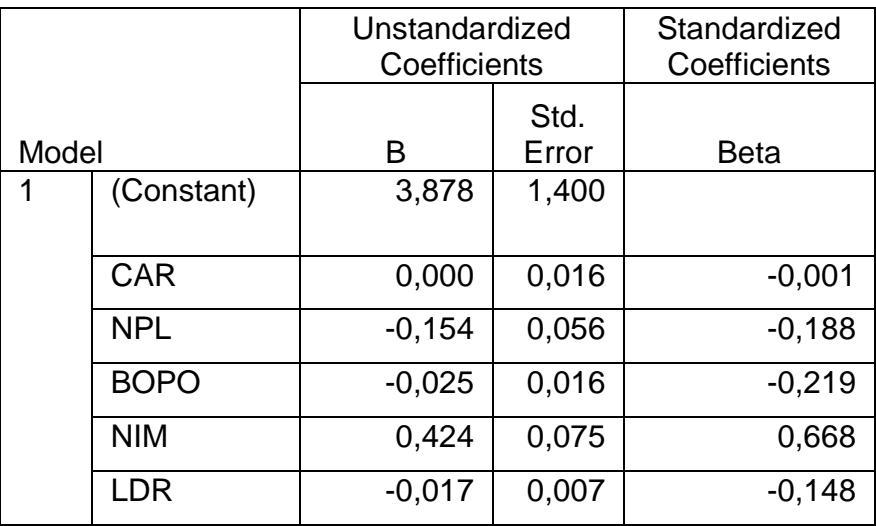

a. Dependent Variabel: ROA

Sumber : Data SPSS 23 (2020), diolah

Berdasarkan Tabel 7, maka didapat model regresi linear berganda sebagai berikut : $Y=3,878+0,000 X_{1}-0,154 X_{2}-0,025 X_{3}+0,424 X_{4}-$

$$
0,017 X_{5}+y+e
$$

Dimana:

$\mathrm{Y}=$ Return On Asset (ROA)

$\mathrm{X}_{1}=$ Capital Adequacy Ratio (CAR)

$\mathrm{X}_{2}=$ Non Performing Loan (NPL)

$\mathrm{X} 3$ = Biaya Operasional Pendapatan Operasional (BOPO)

$\mathrm{X} 4=$ Net Interest Margin (NIM)

X5 = Loan to Deposit Ratio (LDR)

$\mathrm{e}=$ eror

Dari persamaan regresi linier berganda di atas dapat diinterpretasikan sebagai berikut :

1. Nilai konstanta sebesar 3,878 bernilai positif artinya jika semua variabel yaitu Capital Adequacy Ratio (CAR) $\left(\mathrm{X}_{1}\right)$, Non Performing Loan (NPL) $\left(\mathrm{X}_{2}\right)$, Biaya Operasional Pendapatan Operasional (BOPO) $\left(\mathrm{X}_{3}\right)$, Net Interest Margin (NIM) $\left(\mathrm{X}_{4}\right)$, dan Loan to Deposit Ratio (LDR) $\left(\mathrm{X}_{5}\right)$ bernilai konstanta, maka variabel ROA (Y) akan mengalami kenaikan sebesar 3,878 satuan.

2. Koefisien regresi untuk variabel Capital Adequacy Ratio (CAR) $\left(\mathrm{X}_{1}\right)$ bernilai 0,000 yang berarti mempunyai nilai positif, hal ini menunjukan hubungan searah antara Capital 
Jurnal Ekonomi : Journal of Economic p-ISSN: 2087-8133 | e-ISSN: 2528-326X

Adequacy Ratio (CAR) $\left(\mathrm{X}_{1}\right)$ terhadap ROA $(\mathrm{Y})$ artinya jika setiap terjadi kenaikan Capital Adequacy Ratio (CAR) $\left(\mathrm{X}_{1}\right)$ sebesar satu satuan maka ROA $(\mathrm{Y})$ mengalami kenaikan sebesar 0,000.

3. Koefisien regresi untuk variabel Non Performing Loan (NPL) $\left(\mathrm{X}_{2}\right)$ bernilai $-0,154$ yang berarti mempunyai nilai negatif, hal ini menunjukan hubungan tidak searah antara Non Performing Loan (NPL) $\left(\mathrm{X}_{2}\right)$ terhadap ROA ( $Y$ ) artinya jika setiap terjadi kenaikan Non Performing Loan (NPL) $\left(\mathrm{X}_{2}\right)$ sebesar satu satuan maka ROA (Y) mengalami penurunan sebesar 0,154.

4. Koefisien regresi untuk variabel Biaya Operasional Pendapatan Operasional (BOPO) $\left(X_{3}\right)$ bernilai $-0,025$ yang berarti mempunyai nilai negatif, hal ini menunjukan hubungan tidak searah antara Biaya Operasional Pendapatan Operasional (BOPO) $\left(\mathrm{X}_{3}\right)$ terhadap ROA $(Y)$ artinya jika setiap terjadi kenaikan Non Performing Loan (NPL) $\left(\mathrm{X}_{3}\right)$ sebesar satu satuan maka ROA (Y) mengalami penurunan sebesar 0,025.

5. Koefisien regresi untuk variabel Net Interest Margin (NIM) $\left(\mathrm{X}_{4}\right)$ bernilai 0,424 yang berarti mempunyai nilai positif, hal ini menunjukan hubungan searah antara Net Interest Margin (NIM) $\left(\mathrm{X}_{4}\right)$ terhadap ROA (Y) artinya jika setiap terjadi kenaikan Net Interest Margin (NIM) $\left(X_{4}\right)$ sebesar satu satuan maka ROA ( $Y$ ) mengalami kenaikan sebesar 0,424.

6. Koefisien regresi untuk variabel Loan to Deposit Ratio (LDR) ( $\mathrm{X}_{5}$ ) bernilai-0,017 yang berarti mempunyai nilai negatif, hal ini menunjukan hubungan tidak searah antara Loan to Deposit Ratio (LDR) $\left(\mathrm{X}_{5}\right)$ terhadap ROA (Y) artinya jika setiap terjadi kenaikan Loan to Deposit Ratio (LDR) $\left(X_{5}\right)$ sebesar satu satuan maka ROA (Y) mengalami penurunan sebesar 0,017.

\section{Analisis Koefisien Korelasi}

Hasil pengujian analisis koefisien korelasi secara parsial yang dapat dilihat pada Tabel 8 sebagai berikut :

\section{Tabel 8}

Hasil Uji Koefisien Korelasi Parsial

\begin{tabular}{|c|c|c|c|c|c|c|c|}
\hline \multicolumn{8}{|c|}{ Correlations } \\
\hline & & $\mathrm{ROA}$ & CAR & NPL & BOPO & NIM & LDR \\
\hline \multirow{6}{*}{$\begin{array}{l}\text { Pearson } \\
\text { Correlati } \\
\text { on }\end{array}$} & ROA & 1,000 & $-0,140$ & $-0,669$ & $-0,948$ & 0,933 & $-0,179$ \\
\hline & CAR & $-0,140$ & 1,000 & $-0,159$ & 0,097 & $-0,317$ & $-0,431$ \\
\hline & NPL & $-0,669$ & $-0,159$ & 1,000 & 0,652 & $-0,472$ & 0,156 \\
\hline & BOPO & $-0,948$ & 0,097 & 0,652 & 1,000 & $-0,852$ & 0,249 \\
\hline & NIM & 0,933 & $-0,317$ & $-0,472$ & $-0,852$ & 1,000 & 0,078 \\
\hline & LDR & $-0,179$ & $-0,431$ & 0,156 & 0,249 & 0,078 & 1,000 \\
\hline \multirow{6}{*}{$\begin{array}{l}\text { Sig. (1- } \\
\text { tailed) }\end{array}$} & ROA & & 0,324 & 0,006 & 0,000 & 0,000 & 0,279 \\
\hline & CAR & 0,324 & & 0,302 & 0,376 & 0,145 & 0,071 \\
\hline & NPL & 0,006 & 0,302 & & 0,008 & 0,052 & 0,306 \\
\hline & BOPO & 0,000 & 0,376 & 0,008 & & 0,000 & 0,206 \\
\hline & NIM & 0,000 & 0,145 & 0,052 & 0,000 & & 0,400 \\
\hline & LDR & 0,279 & 0,071 & 0,306 & 0,206 & 0,400 & \\
\hline \multirow[t]{6}{*}{$\mathrm{N}$} & ROA & 13 & 13 & 13 & 13 & 13 & 13 \\
\hline & CAR & 13 & 13 & 13 & 13 & 13 & 13 \\
\hline & NPL & 13 & 13 & 13 & 13 & 13 & 13 \\
\hline & BOPO & 13 & 13 & 13 & 13 & 13 & 13 \\
\hline & NIM & 13 & 13 & 13 & 13 & 13 & 13 \\
\hline & LDR & 13 & 13 & 13 & 13 & 13 & 13 \\
\hline
\end{tabular}

Sumber : Data SPSS 23 (2020), diolah

Dilihat dari Tabel 8 menunjukan bahwa:

1. Antara CAR dengan ROA memiliki korelasi secara parsial sebesar - 0, 140 artinya hasil ini berada pada interval 0,00-0,199. Dengan berada pada interval tersebut maka tingkat hubungan variabel tersebut sangat lemah dan tidak searah

2. Antara NPL dengan ROA memiliki korelasi secara parsial sebesar - 0,669 artinya hasil ini berada pada interval $0,60-0,799$. Dengan berada pada interval tersebut maka tingkat hubungan variabel tersebut Kuat dan tidak searah

3. Antara BOPO dengan ROA memiliki korelasi secara parsial sebesar - 0,948 artinya hasil ini berada pada interval 0,80-1. Dengan berada pada interval tersebut maka tingkat hubungan variabel tersebut sangat kuat dan tidak searah

4. Antara NIM dengan ROA memiliki korelasi secara parsial sebesar - 0,933 artinya hasil ini berada pada interval 0,80-1. Dengan berada pada interval tersebut maka tingkat hubungan variabel tersebut sangat kuat dan tidak searah

5. Antara LDR dengan ROA memiliki korelasi secara parsial sebesar - 0,179 artinya hasil ini berada pada interval 0,00-0,199. Dengan berada pada interval tersebut maka tingkat hubungan variabel tersebut sangat lemah dan tidak searah

\section{Tabel 9}

Hasil Uji Koefisien Korelasi Berganda 


\begin{tabular}{|c|c|c|c|c|c|}
\hline \multicolumn{6}{|c|}{ Model Summary } \\
\hline Model & R & $\begin{array}{c}\mathrm{R} \\
\text { Square }\end{array}$ & $\begin{array}{c}\text { Adjusted } \\
\text { R } \\
\text { Square }\end{array}$ & $\begin{array}{c}\text { Std. } \\
\text { Error of } \\
\text { the } \\
\text { Estimate }\end{array}$ & $\begin{array}{l}\text { Durbin- } \\
\text { Watson }\end{array}$ \\
\hline 1 &, $992^{a}$ & 0,984 & 0,972 & 0,09364 & 1,447 \\
\hline
\end{tabular}

Sumber : Data SPSS 23 (2020), diolah

Berdasarkan Tabel 9, maka dapat diketahui Korelasi antara Capital Adequacy Ratio (CAR) $\left(\mathrm{X}_{1}\right)$, Non Performing Loan (NPL) $\left(\mathrm{X}_{2}\right)$, Biaya Operasional Pendapatan Operasional (BOPO) $\left(\mathrm{X}_{3}\right)$, Net Interest Margin (NIM) $\left(\mathrm{X}_{4}\right)$, dan Loan to Deposit Ratio (LDR) $\left(\mathrm{X}_{5}\right)$ dengan ROA $(\mathrm{Y})$ adalah sebesar 0,992. Berdasarkan kriteria korelasi termasuk pada interval 0,80 - 1,000 yang artinya hubungan antara kedua variabel sangat kuat dan searah, jika setiap terjadi kenaikan Capital Adequacy Ratio (CAR) (X) , Non Performing Loan (NPL) $\left(\mathrm{X}_{2}\right)$, Biaya Operasional Pendapatan Operasional (BOPO) $\left(\mathrm{X}_{3}\right)$, Net Interest Margin (NIM) $\left(\mathrm{X}_{4}\right)$, dan Loan to Deposit Ratio (LDR) $\left(\mathrm{X}_{5}\right)$, dapat meningkatkan ROA $(\mathrm{Y})$. begitupun sebaliknya, jika setiap terjadi penurunan Capital Adequacy Ratio (CAR) $\left(\mathrm{X}_{1}\right)$, Non Performing Loan (NPL) $\left(\mathrm{X}_{2}\right)$, Biaya Operasional Pendapatan Operasional (BOPO) $\left(\mathrm{X}_{3}\right)$, Net Interest Margin (NIM) $\left(\mathrm{X}_{4}\right)$, dan Loan to Deposit Ratio (LDR) ( $\left.\mathrm{X}_{5}\right)$ maka dapat menurunkan ROA (Y).

\section{Analisis Koefisien Determinasi}

Koefisien determinasi digunakan untuk melihat seberapa besar pengaruh variabel independen terhadap variabel dependen dalam bentuk persen (\%). Hasil analisis koefisien determinasi sebagai berikut :

Tabel 10

Hasil Uji Analisis Koefisien Determinasi Secara Simultan Model Summary ${ }^{\text {b }}$

\begin{tabular}{|l|c|r|r|r|r|}
\hline Model & $\mathrm{R}$ & $\begin{array}{c}\mathrm{R} \\
\text { Square }\end{array}$ & $\begin{array}{c}\text { Adjusted } \\
\mathrm{R} \\
\text { Square }\end{array}$ & $\begin{array}{c}\text { Std. } \\
\text { Error of } \\
\text { the } \\
\text { Estimate }\end{array}$ & $\begin{array}{c}\text { Durbin- } \\
\text { Watson }\end{array}$ \\
\hline 1 &, $992^{\mathrm{a}}$ & 0,984 & 0,972 & 0,09364 & 1,447 \\
\hline
\end{tabular}

a. Predictors: (Constant), LDR, NIM, NPL, CAR, BOPO

b. Dependent Variabel: ROA

Sumber : Data SPSS 23 (2020), diolah

Berdasarkan Tabel 10, diperoleh nilai koefisien determinasi sebesar 0,984 atau 98,4\%.
Hal ini menunjukan bahwa presentase hubungan Capital Adequacy Ratio (CAR) ( $\left.\mathrm{X}_{1}\right)$, Non Performing Loan (NPL) $\left(\mathrm{X}_{2}\right)$, Biaya Operasional Pendapatan Operasional (BOPO) $\left(\mathrm{X}_{3}\right)$, Net Interest Margin (NIM) $\left(\mathrm{X}_{4}\right)$, dan Loan to Deposit Ratio (LDR) ( $\left.X_{5}\right)$ sebesar $98,4 \%$ sedangkan sisanya sebesar $1,6 \%$ dipengaruhi oleh faktor lain.

\section{Uji Hipotesis}

Uji Parsial (Uji t)

Uji t digunakan untuk melihat Pengujian hipotesis secara parsial (uji t) digunakan untuk mengetahui seberapa besar pengaruh variabel CAR, NPL, BOPO, NIM dan LDR terhadap Return On Assets (ROA) pada PT Bank Tabungan Negara,Tbk Periode Tahun 2008-2020. Pengujian ini membantu untuk mengetahui variabel yang diteliti berpengaruh secara signifikan atau tidak.

Tabel 11

\section{Hasil Perhitungan Pengujian Parsial (Uji t)}

\begin{tabular}{|c|c|c|c|c|c|c|}
\hline \multirow{2}{*}{\multicolumn{2}{|c|}{ Model }} & \multicolumn{2}{|c|}{$\begin{array}{l}\text { Unstandardized } \\
\text { Coefficients }\end{array}$} & \multirow{3}{*}{$\begin{array}{c}\begin{array}{c}\text { Standardi } \\
\text { zed } \\
\text { Coefficie } \\
\text { nts }\end{array} \\
\\
\text { Beta }\end{array}$} & \multirow{3}{*}{$\frac{\mathrm{t}}{2,771}$} & \multirow{3}{*}{$\begin{array}{l}\text { Sig. } \\
0,028\end{array}$} \\
\hline & & \multirow{2}{*}{$\frac{B}{3,878}$} & \multirow{2}{*}{$\begin{array}{c}\begin{array}{c}\text { Std. } \\
\text { Error }\end{array} \\
1,400\end{array}$} & & & \\
\hline 1 & $\begin{array}{l}\text { (Const } \\
\text { ant) }\end{array}$ & & & & & \\
\hline & CAR & 0,000 & 0,016 & $-0,001$ & $-0,018$ & 0,986 \\
\hline & NPL & $-0,154$ & 0,056 & $-0,188$ & $-2,729$ & 0,029 \\
\hline & BOPO & $-0,025$ & 0,016 & $-0,219$ & $-1,603$ & 0,153 \\
\hline & NIM & 0,424 & 0,075 & 0,668 & 5,630 & 0,001 \\
\hline & LDR & $-0,017$ & 0,007 & $-0,148$ & $-2,256$ & 0,059 \\
\hline
\end{tabular}

Sumber : Data SPSS 23 (2020), diolah

Berdasarkan Tabel 11, diperoleh data bahwa variabel CAR $\left(X_{1}\right)$ memiliki tingkat signifkasinsi sebesar 0,986>0,05. Hal ini menandakan bahwa variabel $\operatorname{CAR}\left(\mathrm{X}_{1}\right)$ secara parsial tidak berpengaruh signifikan terhadap ROA. Sedangkan untuk variabel NPL $\left(X_{2}\right)$ memiliki tingkat signifikansi sebesar 0,029< 0,05 , hal ini berarti variabel NPL $\left(X_{1}\right)$ secara parsial berpengaruh signifikan terhadap ROA. Variabel BOPO $\left(X_{3}\right)$ memiliki tingkat signifikansi sebesar 0,153>0,05, oleh karena itu, BOPO $\left(X_{3}\right)$ secara parsial tidak berpengaruh terhadap ROA. Variabel NIM $\left(X_{4}\right)$ memiliki tingkat signifikansi sebesar 0,001 <0,05, hal ini berarti NIM $\left(X_{4}\right)$ secara parsial berpengaruh terhadap ROA. LDR 
$\left(X_{5}\right)$ memiliki tingkat signifikansi sebesar 0,059 $>0,05$, berarti LDR $\left(X_{5}\right)$ secara parsial tidak berpengaruh signifikan terhadap ROA pada PT Bank Tabungan Negara,Tbk Periode Tahun 20082020.

\section{Uji Simultan (Uji F)}

Uji $F$ dipakai untuk melihat variabelvariabel independen terhadap variabel dependen secara keseluruhan dari anova test. Hasil perhitungan adalah sebagai berikut :

Tabel 12

\section{Hasil Perhitungan Pengujian Simultan (Uji}

F)

ANOVA $^{\mathrm{a}}$

\begin{tabular}{|l|l|r|r|r|r|l|}
\hline \multicolumn{2}{|c|}{ Model } & $\begin{array}{c}\text { Sum of } \\
\text { Squares }\end{array}$ & df & $\begin{array}{c}\text { Mean } \\
\text { Square }\end{array}$ & F & Sig. \\
\hline 1 & Regression & 3,702 & 5 & 0,740 & 84,451 &, $000^{\mathrm{b}}$ \\
\cline { 3 - 7 } & Residual & 0,061 & 7 & 0,009 & & \\
\cline { 2 - 7 } & Total & 3,764 & 12 & & & \\
\hline
\end{tabular}

a. Dependent Variabel: ROA

b. Predictors: (Constant), LDR, NIM, NPL, CAR, BOPO

Sumber : Data SPSS 23 (2020), diolah

Berdasarkan Tabel 12, diperoleh data bahwa Capital Adequacy Ratio (CAR) $\left(\mathrm{X}_{1}\right)$, Non Performing Loan (NPL) $\left(\mathrm{X}_{2}\right)$, Biaya Operasional Pendapatan Operasional (BOPO) $\left(\mathrm{X}_{3}\right)$, Net Interest Margin (NIM) $\left(\mathrm{X}_{4}\right)$, dan Loan to Deposit Ratio (LDR) $\left(\mathrm{X}_{5}\right)$ terhadap Return On Assets (ROA) (Y) memiliki nilai signifikansi sebesar $0,000<$ dari 0,05. Dengan demikian secara simultan Capital Adequacy Ratio (CAR) (X) , Non Performing Loan (NPL) $\left(\mathrm{X}_{2}\right)$, Biaya Operasional Pendapatan Operasional (BOPO) $\left(\mathrm{X}_{3}\right)$, Net Interest Margin (NIM) $\left(\mathrm{X}_{4}\right)$, dan Loan to Deposit Ratio (LDR) ( $\mathrm{X}_{5}$ ) berpengaruh signifikan terhadap Return On Assets (ROA) (Y).

\section{Kesimpulan}

Berdasarkan penelitian yang dilakukan maka didapatkan kesimpulan sebagai berikut:

1. Return On Assets (ROA) (Y) pada PT Bank Tabungan Negara,Tbk Periode Tahun 20082020 cenderung flutktuasi menurun. Nilai Rata-rata (mean) Return On Assets (ROA) dari Periode 2008 sampai 2020 yaitu 1,4969 dengan standar deviasi sebesar 0,56005.

2. Capital Adequacy Ratio (CAR) $\left(\mathrm{X}_{1}\right)$ pada PT Bank Tabungan Negara,Tbk Periode Tahun 2008-2020 cenderung flutktuasi menurun. Nilai Rata-rata (mean) Capital Adequacy Ratio
(CAR) Periode 2008-2020 yaitu 17,6308 dengan standar deviasi sebesar 2,11415.

3. Non Performing Loan (NPL) $\left(\mathrm{X}_{2}\right)$ pada PT Bank Tabungan Negara,Tbk Periode Tahun 2008-2020 cenderung fluktuasi naik. Nilai Rata-rata (mean) Non Performing Loan (NPL) Periode 2008-2020 yaitu 3,5085 dengan standar deviasi sebesar 0,68586.

4. Biaya Operasional Pendapatan Operasional (BOPO) $\left(X_{3}\right)$ pada pada PT Bank Tabungan Negara,Tbk Periode Tahun 2008-2020 fluktuatif tiap tahunnya. Nilai Rata-rata (mean) Biaya Operasional Pendapatan Operasional (BOPO) Periode 2008-2020 yaitu 85,7892 dengan standar deviasi sebesar 4,9018 .

5. Net Interest Margin (NIM) (X) pada pada PT Bank Tabungan Negara,Tbk Periode Tahun 2008-2020 cenderung fluktuasi menurun. Nilai Rata-rata (mean) Net Interest Margin (NIM) Periode 2008-2020 yaitu 4,8046 dengan standar deviasi sebesar 0,88255

6. Loan to Deposit Ratio (LDR) ( $\mathrm{X}_{5}$ ) pada pada PT Bank Tabungan Negara,Tbk Periode Tahun 2008-2020 cenderung fluktuasi naik. Nilai Rata-rata (mean) Loan to Deposit Ratio (LDR) Periode 2008-2020 yaitu 17,6308 dengan standar deviasi sebesar 2,11415.

7. Secara parsial, Capital Adequacy Ratio (CAR) $\left(\mathrm{X}_{1}\right)$ tidak berpengaruh signifikan terhadap Return On Assets (ROA) pada PT Bank Tabungan Negara,Tbk Periode Tahun 20082020.

8. Secara parsial, Non Performance Loan (NPL) $\left(\mathrm{X}_{2}\right)$ berpengaruh signifikan terhadap Return On Assets (ROA) pada PT Bank Tabungan Negara,Tbk Periode Tahun 2008-2020.

9. Secara parsial, Biaya Operasional Pendapatan Operasional (BOPO) $\left(\mathrm{X}_{3}\right)$ tidak berpengaruh signifikan terhadap Return On Assets (ROA) pada PT Bank Tabungan Negara,Tbk Periode Tahun 2008-2020.

10. Secara parsial, Net Interest Margin (NIM) $\left(\mathrm{X}_{4}\right)$ berpengaruh signifikan terhadap Return On Assets (ROA) pada PT Bank Tabungan Negara,Tbk Periode Tahun 2008-2020.

11. Secara parsial, Loan to Deposit Ratio (LDR) $\left(\mathrm{X}_{5}\right)$ tidak berpengaruh signifikan terhadap Return On Assets (ROA) pada PT Bank Tabungan Negara,Tbk Periode Tahun 2008-2020.

12. Secara simultan, Return On Asset (ROA) demikian secara simultan Capital Adequacy 
Ratio (CAR) $\left(\mathrm{X}_{1}\right)$, Non Performing Loan (NPL) $\left(X_{2}\right)$, Biaya Operasional Pendapatan Operasional (BOPO) $\left(\mathrm{X}_{3}\right)$, Net Interest Margin (NIM) $\left(\mathrm{X}_{4}\right)$, dan Loan to Deposit Ratio (LDR) $\left(X_{5}\right)$ berpengaruh signifikan terhadap Return On Assets (ROA) (Y).

\section{Rekomendasi Kebijakan}

Maka saran rekomendasi kebijakan yang dapat diberikan adalah sebagai berikut :

A. Bagi Bank

Bank diharapkan menjaga kinerja bisnis dan memperbaiki kualitas aset, terutama rasio kredit bermasalah (Non Performing Loanl NPL). Dalam rangka memelihara kelangsungan bisnis bank, Bank perlu tetap mengelola eksposur risiko kredit pada tingkat yang memadai. Selain itu bank sebaiknya dapat menurunkan cost of Fund agar ROA dapat meningkat.

B. Bagi Investor

Sebelum menanamkan modal atau berinvestasi di Bursa Efek Indonesia (BEI) khususnya pada sub sektor perbankan sebaiknya melakukan analisis fundamental untuk melihat kinerja perusahaan dalam menentukan portofolio investasi pada Perusahaan, agar para investor dapat memprediksi keuntungan dan kerugian yang akan diperoleh apabila berinvestasi pada perusahaan Perbankan tersebut.

\section{Daftar Pustaka}

Achmad, S. (2003). Ekonomi Perbankan. Jakarta: STIE Gunadarma.

Almilia dan Herdiningtyas (2005). Analisis Rasio CAMEL terhadap Prediksi Kondisi Bermasalah Pada Lembaga Perbankan Periode 2000-2002, Jurnal Akuntansi dan Keuangan, Vol. 7 No. 2 November 2005.

Anindita Vania, Herlanto Achmad Anggono.(2016). The Influence of Bank Specific Variabels on NPL and the Implications of NPL, Exchange Rate, and Inflation Rate to Bank Profitability Performance (Case Study: 19 Foreign Exchange Commercial Banks in Indonesia Period 2008-2014). ICMEM, 10 - 12 Agustus 2016. Bali, Indonesia
Bank Indonesia. (2020, Januari 23). Surat Edaran Bank Indonesia No. 6/73/Intern/DPNP perihal Pedoman Sistem Penilaian Tingkat Kesehatan Bank Umum (CAMELS Rating), tanggal 24 Desember 2004, Republik Indonesia, Jakarta.

Bank Indonesia. (2020, Maret 10). Undangundang No. 10 tahun 1998 tentang Perbankan, Republik Indonesia, Jakarta. https://peraturan.bpk.go.id/Home/Details 445486/uu-no-10-tahun-1998

Bank Indonesia. (2020, Januari 7). Peraturan Bank Indonesia No. 9/13/PBI/2007 tanggal 01 November 2007. Jakarta. https://www.ojk.go.id/Files/batchen2/195 .pdf.

Budisantoso Totok, Triandaru Sigit. (2006). Bank dan Lembaga Keuangan Lain. Jakarta : Salemba Empat.

Kasmir. (2014). Bank dan Lembaga Keuangan Lainnya. Edisi Revisi, Cetakan keempatbelas. Jakarta :PT. RajaGrafindo Persada.

Koch, Timothy W, Mac Donald, S. Scot. (2000). Bank Management Fourth Edition. Orlando: The Dryden Press, Harcourt Brace College Publishers.

Mawardi, Wisnu. (2005). Analisa Faktor Faktor yang Mempengaruhi Kinerja Keuangan Bank Umum di Indonesia (Studi Kasus pada Bank Umum dengan Total Asset Kurang dari 1 Triliun). Jurnal Bisnis Strategi, Vol.14, No.1, Juli, pp.83-94

Pinasti, W. F. dan Mustikawati, RR. I. (2018). Pengaruh CAR, BOPO, NPL, NIM dan LDR terhadap Profitabilitas Bank Umum Periode 2011-2015. Jurnal Nominal. $\operatorname{VII}(1), 126-142$

Sudarmawanti, Erna dan Pramono. 2017. Pengaruh CAR, NPL, BOPO, NIM DAN LDR Terhadap ROA (Studi kasus pada Bank Perkreditan Rakyat di Salatiga yang terdaftar di Otoritas Jasa Keuangan 
Tahun 2011-2015). Among Makarti Vol.10

No.19, Juli 2017.

Sugiyono. (2018). Metode Penelitian Kuantitatif, Kualitatif, dan R\&D. Bandung: Alfabeta.

Suharna, J., \& Bertuah, E. (2020). Mendeteksi Faktor Penentu Struktur Modal Pada Sub Sektor Perdagangan Besar (Wholesaler) Dan Retailer Di Indonesia Yang Go Publik. Jurnal Ekonomi: Journal of Economic, 11(02).

Taswan. (2010). Manajemen Perbankan Konsep, Teknik, dan Aplikasi. Edisi Kedua. Yogyakarta: UPP STIM YKPN. 